\title{
Formulasi dan Evaluasi Stabilitas Fisik Sediaan Gel Face Scrub Ekstrak Cucumis sativus L. dan Ampas Kelapa
}

\author{
Nia Yuniarsih*, Annisa Meilinda Sari
}

Program Studi Farmasi, Fakultas Farmasi, Universitas Buana Perjuangan, Karawang, Jawa Barat, Indonesia

*E-mail : nia.yuniarsih@ubpkarawang.ac.id

(Submit 19/12/2021, Revisi 20/12/2021, Diterima 30/12/2021, Terbit 31/12/2021)

\begin{abstract}
Abstrak
Kulit wajah adalah bagian utama tubuh, yang memperlihatkan kesehatan seseorang. Kulit wajah yang terlihat kusam dapat disebabkan karena berbagai macam faktor, salah satunya, yaitu adanya penumpukkan sel kulit mati. Salah satu exfoliate cleanser dalam kategori bahan pembersih dan sebagai penghalus kulit disebut scrub. Penggunaan scrub secara teratur menjadikan kulit tampak halus karena sel kulit mati yang terangkat sehingga mengekspos sel-sel kulit baru. Ampas kelapa memiliki kandungan serat kasar $15,07 \%$ dengan adanya kandungan serat kasar maka ampas kelapa dapat dijadikan scrub yang memiliki butir kasar sehingga dapat mengangkat sel kulit mati. Mentimun merupakan salah satu tanaman yang memiliki aktivitas antioksidan karena adanya kandungan senyawa golongan Fenolik seperti Flavonoid dan Asam Fenolat. Penelitian ini bertujuan untuk melakukan formulasi gel face scrub ekstrak Mentimun dengan ampas kelapa dan dilanjut dengan evaluasi stabilitas fisik. Metode yang digunakan dalam penelitian ini adalah stabilitas dipercepat yang dilakukan selama 3 bulan penyimpanan dalam tiga keadaan yakni suhu ruang $\left(20-25^{\circ} \mathrm{C}\right)$, dibawah sinar matahari, dan suhu $40^{\circ} \mathrm{C}$. Hasil pengujian stabilitas fisik sediaan gel face scrub ekstrak Cucumis sativus.,L dan ampas kelapa yaitu pada pengujian organoleptik berbentuk gel, tidak berbau, dan berwarna bening putih. Hasil nilai $\mathrm{pH}$ dan nilai viskositas membuktikan bahwa semua hasil masuk kedalam standar yang ditentukan, dimana nilai $\mathrm{pH}$ kulit wajah 4,5 - 6,5 dan nilai viskositas 3.000 - 50.000 Centipoise, kemudian hasil tersebut dilanjutkan pengolahan data statistik menggunakan ANOVA Post Hoc Test. Kesimpulan yang didapat yaitu sediaan gel face scrub ekstrak Cucumis sativus.,L dan ampas kelapa stabil pada suhu ruang $\left(20-25^{\circ} \mathrm{C}\right)$ ), dibawah sinar matahari, dan pada suhu $40^{\circ} \mathrm{C}$
\end{abstract}

Kata kunci: ampas kelapa, gel face scrub, Cucumis sativus L, uji stabilitas 


\section{Pendahuluan}

Kulit wajah adalah bagian utama tubuh, yang memperlihatkan kesehatan seseorang ${ }^{(1)}$. Kulit wajah yang sering terlihat kusam dan tidak bercahaya dapat disebabkan karena berbagai macam faktor, salah satunya yaitu dengan adanya penumpukkan sel kulit mati(2). Solusi dari masalah ini adalah dengan melakukan exfoliate.

Exfoliate merupakan suatu proses pengangkatan sel-sel kulit mati tertua yang ada dipermukaan kulit. Salah satu exfoliate cleanser dalam kategori bahan pembersih dan sebagai penghalus kulit disebut $s c r u b^{(3)}$. Scrub adalah produk kosmetik yang memiliki fungsi utama sebagai exfoliant tubuh, menghilangkan kotoran, menghaluskan permukaan kulit, membersihkan kulit, dan memperlancar peredaran darah dalam tubuh(4).

Saat ini bahan alami menjadi lebih populer dalam formulasi modern karena kekhawatiran konsumen tentang bahan sintetis. Berbagai macam olahan bahan alami telah digunakan secara tradisional selama berabad-abad yang lalu untuk perawatan kulit(5). Herbal exfoliate banyak digunakan ke kulit wajah, tangan dan anggota badan lainnya karena dianggap memiliki beberapa aktivitas seperti antimikroba, penghambatan pigmentasi, dan antioksidan(6), salah satunya adalah ampas dari buah kelapa (Cocos nucifera L.).

Buah kelapa dinyatakan memiliki banyak bioaktifitas, termasuk antimikroba, antineoplastik, analgesik, antinflamasi, antimalaria, antivirus, dan antileishmanial( ${ }^{(7)}$. Dalam pembuatan santan, ampas kelapa sering kali tidak dimanfaatkan sehingga menjadi limbah. Dalam penelitian Putri, 2010 ampas kelapa memiliki kandungan nutrien yang cukup, yaitu protein 5,78\%; lemak $38,24 \%$ dan serat kasar $15,07 \%(8)$, dengan adanya kandungan serat kasar maka ampas kelapa dapat dijadikan scrub yang memiliki butir kasar sehingga dapat mengangkat sel kulit mati ${ }^{(9)}$. Selain kelapa, sumber antioksidan juga dapat ditemukan pada Cucumis sativus L.

Cucumis sativus L. atau dalam bahasa Indonesia sering disebut Mentimun merupakan salah satu tanaman yang memiliki aktivitas antioksidan(10). Efek antioksidan pada mentimun karena adanya kandungan senyawa golongan Fenolik, seperti Flavonoid dan Asam Fenolat ${ }^{(11)}$.

Berdasarkan latar belakang diatas, maka penelitian ini bertujuan untuk melakukan formulasi dilanjut dengan evaluasi stabilitas fisik sediaan gel face scrub ekstrak Cucumis sativus., L dan ampas kelapa.

\section{Metode}

Penelitian ini dilakukan secara eksperimental laboratorium menggunakan metode stabilitas dipercepat. 


\section{Alat}

Alat yang digunakan adalah Magnetic stirer, Viskometer Brookfield NDJ-8S Viscometer, Smart Sensor pH meter AS218, dan Oven.

\section{Bahan}

Bahan yang digunakan adalah ekstrak Cucumis sativus.,L, Ampas Kelapa, Carbomer, Gliserin, Sodium Lauryl Sulfate , Asam sitrat, Triethanolamine, dan Na-benzoat.

\section{Formulasi Sediaan}

Tabel 1. Formula Sediaan Gel Face Scrub Ekstrak Cucumis sativus., L dan Ampas Kelapa

\begin{tabular}{|c|c|c|c|c|c|}
\hline \multirow{2}{*}{ Bahan } & \multicolumn{4}{|c|}{ Konsentrasi } & \multirow{2}{*}{ Kegunaan } \\
\hline & F0 & $\mathbf{F 1}$ & F2 & F3 & \\
\hline Ekstrak Cucumis sativus L & - & $2 \%$ & $4 \%$ & $6 \%$ & Zat aktif \\
\hline Ampas Kelapa & - & $2 \%$ & $2 \%$ & $2 \%$ & Scrub \\
\hline Carbomer & $1 \%$ & $1 \%$ & $1 \%$ & $1 \%$ & Gelling agent \\
\hline Na-benzoat & $0,1 \%$ & $0,1 \%$ & $0,1 \%$ & $0,1 \%$ & Pengawet \\
\hline Gliserin & $8 \%$ & $8 \%$ & $8 \%$ & $8 \%$ & Humektan \\
\hline Sodium Lauryl Sulfate & $2 \%$ & $2 \%$ & $2 \%$ & $2 \%$ & Foaming agent \\
\hline Asam Sitrat & $1 \%$ & $1 \%$ & $1 \%$ & $1 \%$ & Buffering agent \\
\hline Triethanolamine & $3 \%$ & $3 \%$ & $3 \%$ & $3 \%$ & Alkalizing agent \\
\hline Aquadest & $\begin{array}{ll}\text { Add } & 100 \\
\mathrm{ml} & \end{array}$ & $\begin{array}{ll}\text { Add } & 100 \\
\mathrm{ml} & \end{array}$ & $\begin{array}{ll}\text { Add } & 100 \\
\mathrm{ml} & \end{array}$ & $\begin{array}{ll}\text { Add } & 100 \\
\mathrm{ml}\end{array}$ & Pelarut \\
\hline
\end{tabular}

\section{Pembuatan ekstrak Cucumis sativus $\mathrm{L}$}

Pembuatan ekstrak Cucumis sativus L dengan metode maserasi.

\section{Pembuatan Gel}

Masukkan aquadest kedalam beaker glass tambah gliserin dan $\mathrm{Na-benzoat,} \mathrm{tunggu}$ hingga Na-benzoat larut dan masukkan ekstrak Cucumis sativus L, kemudian masukan Sodium Lauryl Sulfate dan Asam Sitrat, stirrer hingga homogen. Selanjutnya masukkan Carbomer sampai tidak ada gumpalan dan mengembang berbentuk gel. Tambahkan Triethanolamin hingga teraduk rata dan yang terakhir masukkan ampas kelapa yang telah ditimbang kedalam beaker glass.

\section{Hasil dan Pembahasan}

\section{Skrining Fitokimia}


Tabel 2. Hasil Skrining Fitokimia Ekstrak Cucumis sativus., L

\begin{tabular}{|c|c|c|c|}
\hline Senyawa & Pereaksi & Hasil Pengamatan & Keterangan \\
\hline Flavonoid & $1 \mathrm{ml}$ ekstrak+ 0,1 bubuk mg & Larutan kekuningan & + \\
\hline Alkaloid & $1 \mathrm{ml}$ ekstrak + $2 \mathrm{ml} \mathrm{HCl} 2 \mathrm{~N}$ & $\begin{array}{l}\text { - Mayer = larutan kecoklatan } \\
\text { - Dragendrof = larutan jingga }\end{array}$ & $\begin{array}{l}- \\
+ \\
+\end{array}$ \\
\hline Fenolik & $\begin{array}{c}2 \text { ml ekstrak }+2 \text { tetes larutan } \\
\mathrm{FeCl} 1 \%\end{array}$ & Larutan kekuningan & + \\
\hline Saponin & $\begin{array}{l}2 \mathrm{ml} \text { ekstrak }+5 \mathrm{ml} \text { aquadest } \\
+10 \text { tetes } \mathrm{KOH} \text {, lalu dikocok } \\
5 \text { menit }\end{array}$ & Tidak ada busa & - \\
\hline Tanin & $\begin{array}{c}2 \mathrm{ml} \text { esktrak kemudian } \\
\text { dipanaskan }+3 \mathrm{ml} \mathrm{FeCl} 1 \%\end{array}$ & Larutan jingga kecoklatan & - \\
\hline Steroid & $\begin{array}{c}2 \mathrm{ml} \text { ekstrak }+3 \text { tetes } \mathrm{HCl} \\
\text { pekat }+1 \text { tetes } \mathrm{H}_{2} \mathrm{SO}_{4} \text { pekat }\end{array}$ & Larutan coklat tua & - \\
\hline
\end{tabular}

\section{Uji Organoleptik}

Tabel 3. Hasil Uji Organoleptik Sediaan Gel Face Scrub Ekstrak Cucumis sativus.,L dan Ampas Kelapa

\begin{tabular}{|c|c|c|c|c|}
\hline \multirow{3}{*}{ Formulasi } & \multirow{3}{*}{ Suhu } & \multicolumn{3}{|c|}{ Hasil Pengamatan } \\
\hline & & \multicolumn{3}{|c|}{ Parameter : } \\
\hline & & Bentuk & Warna & Bau \\
\hline \multirow{3}{*}{ Fo } & $\begin{array}{l}\text { Suhu Ruang (20- } \\
\left.25^{\circ} \mathrm{C}\right)\end{array}$ & Gel & Bening & $\begin{array}{l}\text { Tidak } \\
\text { berbau }\end{array}$ \\
\hline & $\begin{array}{c}\text { Dibawah Sinar } \\
\text { Matahari }\end{array}$ & Gel & Bening & $\begin{array}{c}\text { Tidak } \\
\text { berbau }\end{array}$ \\
\hline & Suhu $40^{\circ} \mathrm{C}$ & Gel & Bening & $\begin{array}{c}\text { Tidak } \\
\text { berbau }\end{array}$ \\
\hline \multirow{3}{*}{$\mathbf{F 1}$} & $\begin{array}{l}\text { Suhu Ruang (20- } \\
\left.25^{\circ} \mathrm{C}\right)\end{array}$ & Gel & $\begin{array}{l}\text { Bening butir } \\
\text { putih }\end{array}$ & $\begin{array}{c}\text { Tidak } \\
\text { berbau }\end{array}$ \\
\hline & $\begin{array}{c}\text { Dibawah Sinar } \\
\text { Matahari }\end{array}$ & Gel & $\begin{array}{l}\text { Bening butir } \\
\text { putih }\end{array}$ & $\begin{array}{c}\text { Tidak } \\
\text { berbau }\end{array}$ \\
\hline & Suhu $40^{\circ} \mathrm{C}$ & Gel & $\begin{array}{l}\text { Bening butir } \\
\text { putih }\end{array}$ & $\begin{array}{l}\text { Tidak } \\
\text { berbau }\end{array}$ \\
\hline \multirow{3}{*}{ F2 } & $\begin{array}{l}\text { Suhu Ruang (20- } \\
\left.25^{\circ} \mathrm{C}\right)\end{array}$ & Gel & $\begin{array}{l}\text { Bening butir } \\
\text { putih }\end{array}$ & $\begin{array}{c}\text { Tidak } \\
\text { berbau }\end{array}$ \\
\hline & $\begin{array}{c}\text { Dibawah Sinar } \\
\text { Matahari }\end{array}$ & Gel & $\begin{array}{c}\text { Bening butir } \\
\text { putih }\end{array}$ & $\begin{array}{c}\text { Tidak } \\
\text { berbau }\end{array}$ \\
\hline & Suhu $40^{\circ} \mathrm{C}$ & Gel & $\begin{array}{l}\text { Bening butir } \\
\text { putih }\end{array}$ & $\begin{array}{c}\text { Tidak } \\
\text { berbau }\end{array}$ \\
\hline \multirow{3}{*}{ F3 } & $\begin{array}{l}\text { Suhu Ruang }(20- \\
\left.25^{\circ} \mathrm{C}\right)\end{array}$ & Gel & $\begin{array}{l}\text { Bening butir } \\
\text { putih }\end{array}$ & $\begin{array}{c}\text { Tidak } \\
\text { berbau }\end{array}$ \\
\hline & $\begin{array}{c}\text { Dibawah Sinar } \\
\text { Matahari }\end{array}$ & Gel & $\begin{array}{l}\text { Bening butir } \\
\text { putih }\end{array}$ & $\begin{array}{c}\text { Tidak } \\
\text { berbau }\end{array}$ \\
\hline & Suhu $40^{\circ} \mathrm{C}$ & Gel & $\begin{array}{l}\text { Bening butir } \\
\text { putih }\end{array}$ & $\begin{array}{c}\text { Tidak } \\
\text { berbau }\end{array}$ \\
\hline
\end{tabular}




\section{Uji pH pada suhu ruang $\left(20-25^{\circ} \mathrm{C}\right)$}

Nilai Rata-rata pH F0, F1, F2, dan F3 Sediaan Gel Face Scrub Ekstrak Cucumis sativus., L dan Ampas Kelapa pada suhu ruang $\left(20-25^{\circ} \mathrm{C}\right)$

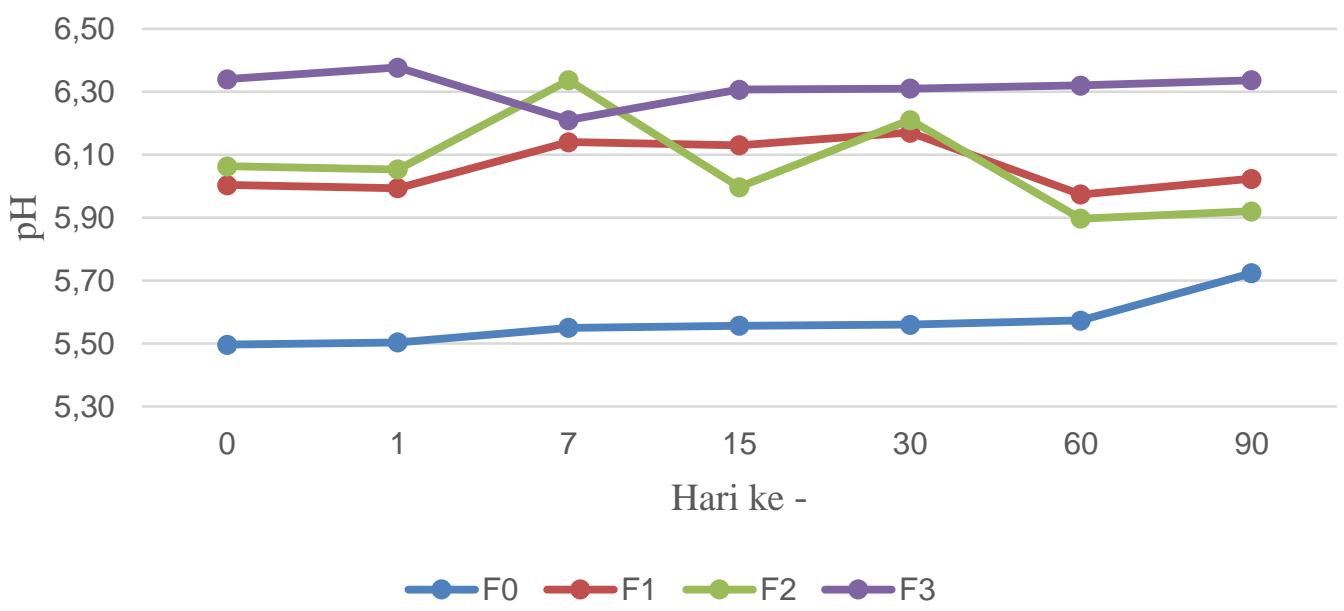

Gambar 1. Nilai Rata-rata pH F0, F1, F2, dan F3 Sediaan Gel Face Scrub Ekstrak Cucumis sativus., L dan Ampas Kelapa pada suhu ruang $\left(20-25^{\circ} \mathrm{C}\right)$

\section{Pada suhu $40^{\circ} \mathrm{C}$}

Nilai Rata-rata pH F0, F1, F2, dan F3 Sediaan Gel Face Scrub Ekstrak Cucumis sativus., L dan Ampas Kelapa pada suhu $40^{\circ} \mathrm{C}$

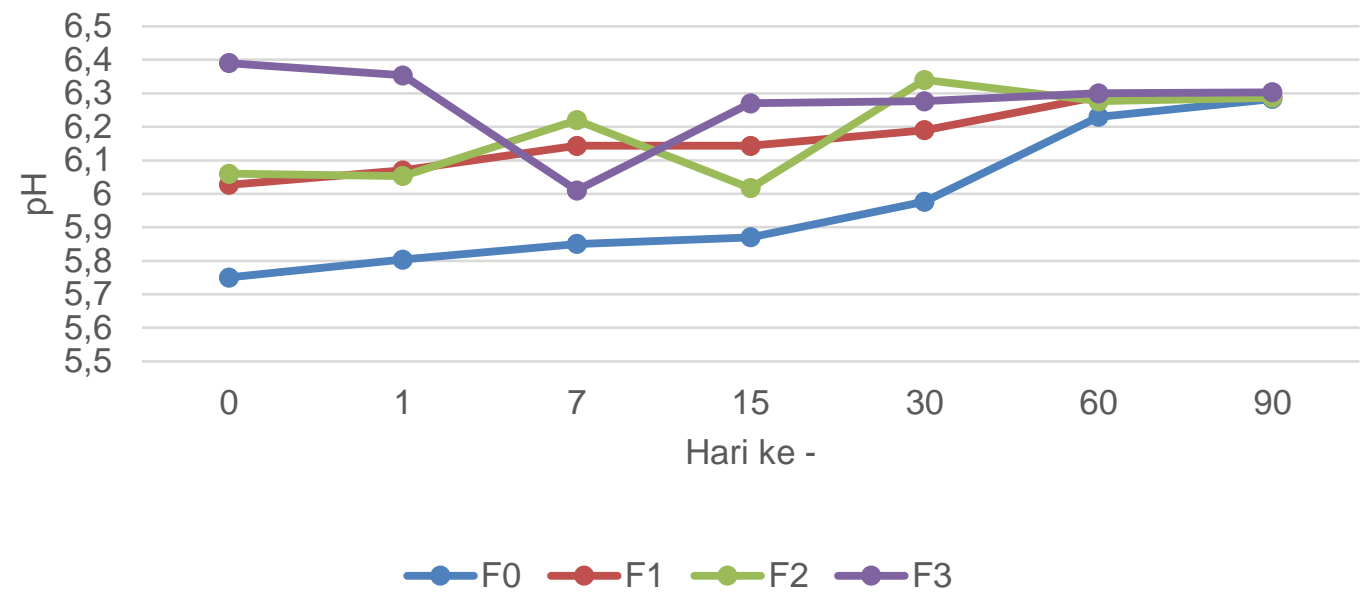

Gambar 2. Nilai Rata-rata pH F0, F1, F2, dan F3 Sediaan Gel Face Scrub Ekstrak Cucumis sativus., L dan Ampas Kelapa pada $40^{\circ} \mathrm{C}$ 


\section{Dibawah Sinar Matahari}

Nilai Rata-rata pH F0, F1, F2, dan F3 Sediaan Gel Face Scrub Ekstrak Cucumis sativus., L dan Ampas Kelapa dibawah Sinar Matahari

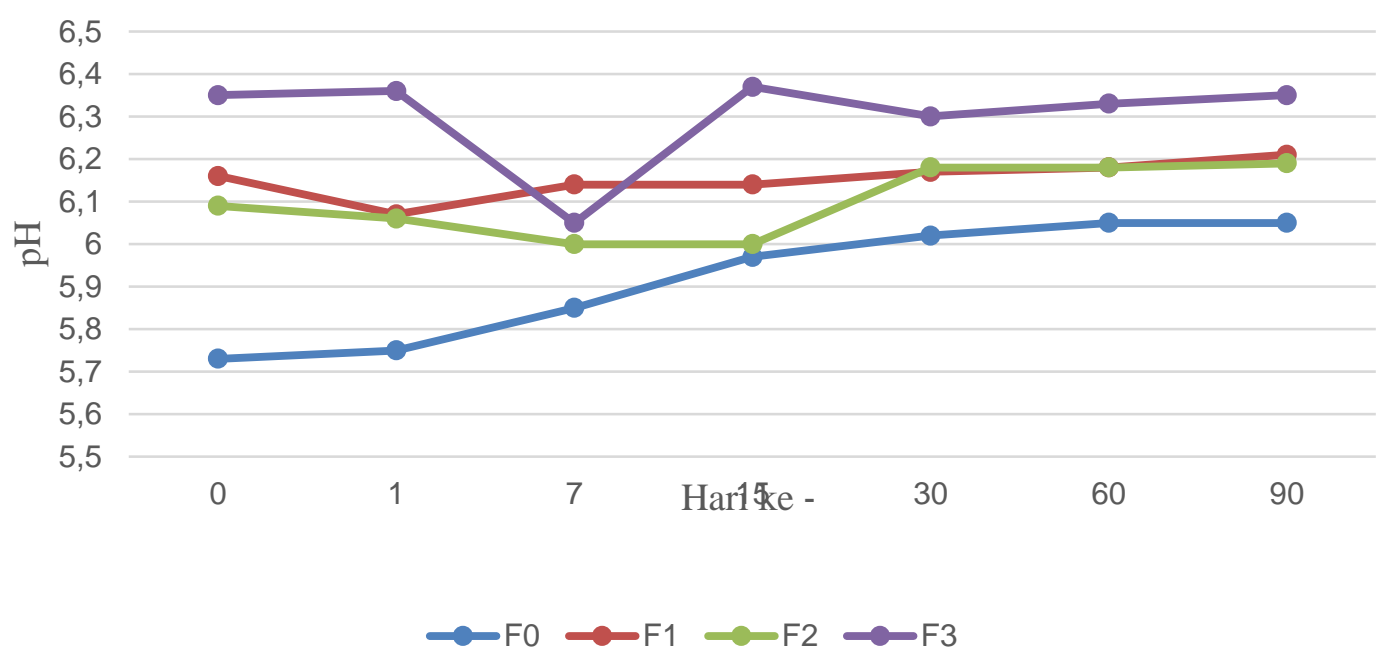

Gambar 3. Nilai Rata-rata pH F0, F1, F2, dan F3 Sediaan Gel Face Scrub Ekstrak Cucumis sativus., L dan Ampas Kelapa dibawah Sinar Matahari

\section{Uji Viskositas}

\section{pada suhu ruang $\left(20-25^{\circ} \mathrm{C}\right)$}

Nilai Rata-rata viskositas F0, F1, F2, dan F3 Sediaan Gel Face Scrub

Ekstrak Cucumis sativus., L dan Ampas Kelapa pada suhu ruang $\left(20-25^{\circ} \mathrm{C}\right)$

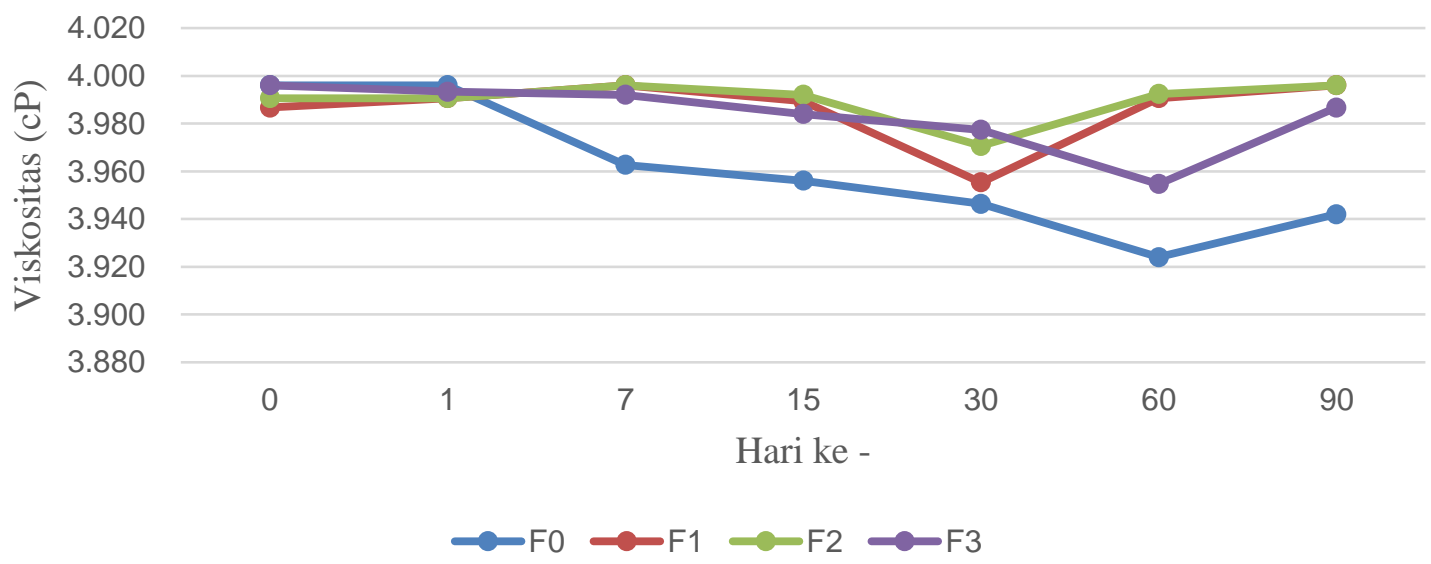

Gambar 4. Nilai Rata-rata viskositas F0, F1, F2, dan F3 Sediaan Gel Face Scrub Ekstrak Cucumis sativus., L dan Ampas Kelapa pada suhu ruang $\left(20-25^{\circ} \mathrm{C}\right)$ 


\section{Pada Suhu $40^{\circ} \mathrm{C}$}

Nilai Rata-rata Viskositas F0, F1, F2, dan F3 Sediaan Gel Face Scrub

Ekstrak Cucumis sativus., L dan Ampas Kelapa pada Suhu $40^{\circ} \mathrm{C}$

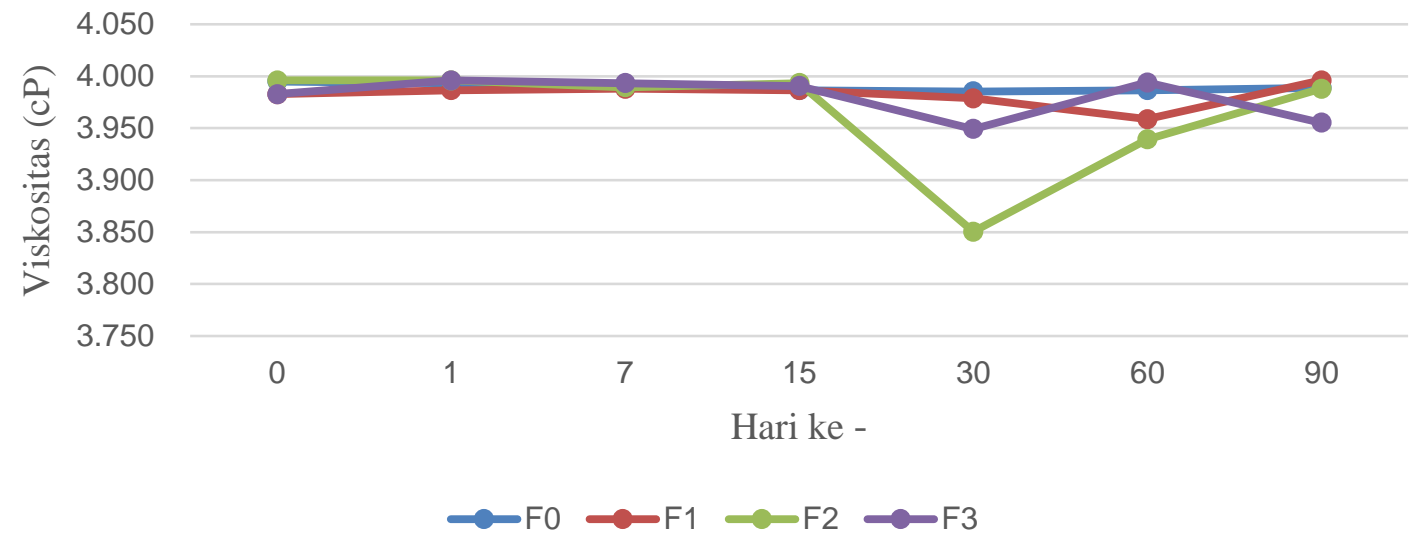

Gambar 5. Nilai Rata-rata Viskositas F0, F1, F2, dan F3 Sediaan Gel Face Scrub Ekstrak Cucumis sativus., L dan Ampas Kelapa pada Suhu $40^{\circ} \mathrm{C}$

\section{Dibawah Sinar Matahari}

Nilai Rata-rata viskositas F0, F1, F2, dan F3 Sediaan Gel Face Scrub Ekstrak Cucumis sativus., L dan Ampas Kelapa dibawah Sinar Matahari

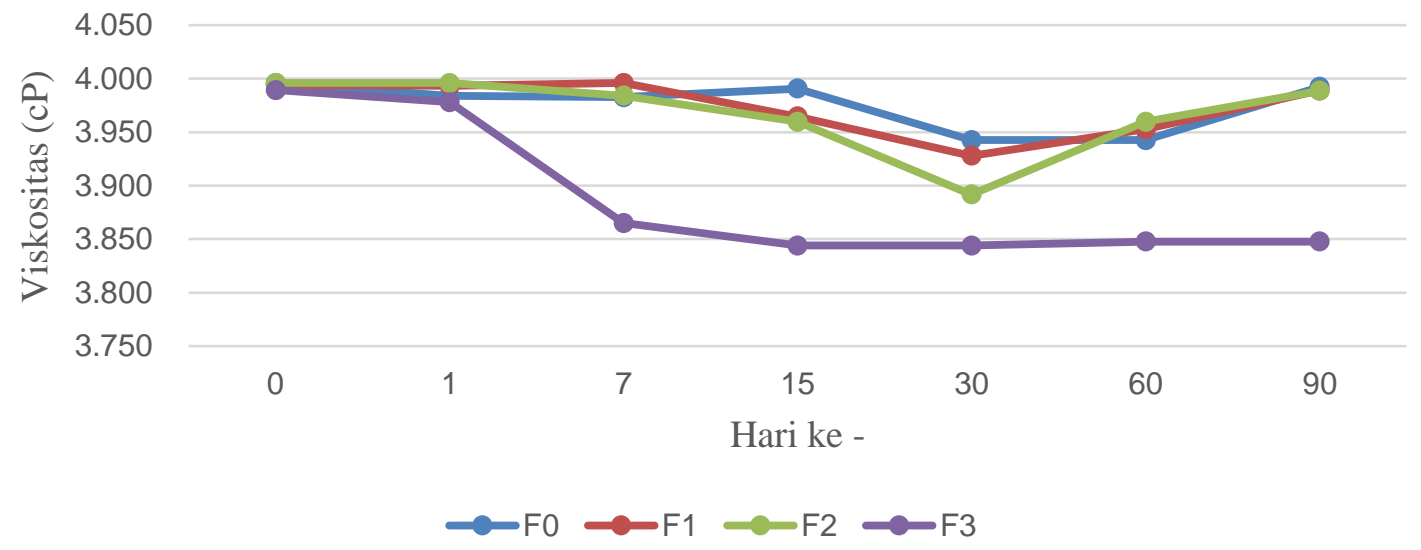

Gambar 6. Nilai Rata-rata viskositas F0, F1, F2, dan F3 Sediaan Gel Face Scrub Ekstrak Cucumis sativus., L dan Ampas Kelapa dibawah Sinar Matahari 


\section{Pembahasan}

\section{Skrining Fitokimia}

berdasarkan tabel 2 hasil skrining fitokimia ekstrak Cucumis sativus., L yang diperoleh dari PT. Phytocemindo Reksa menyatakan bahwa ekstrak Cucumis sativus., L positif mengandung Flavonoid, Alkaloid, dan Fenolik. Pada penelitian Agustin dan Gunawan, 2019 ekstrak buah mentimun positif mengandung Flavonoid, Alkaoid, Fenolik dan Steroid(10). Terdapat perbedaan hasil uji skrining fitokimia yaitu pada penelitian sebelumnya ekstrak buah Cucumis sativus., L positif mengandung Steroid sedangkan pada pengujian saat ini negatif Steroid. Hal tersebut dapat disebabkan karena beberapa faktor dan salah satunya yaitu adanya perbedaan jenis ekstrak yang digunakan. Dalam penelitian terdahulu jenis ekstrak yang digunakan yaitu ekstrak kental sedangkan ekstrak Cucumis sativus.,L yang diperoleh dari PT. Phytocemindo Reksa berupa ekstrak cair. Menurut kajian Ramen et al, 2018 dan Cruz et al, 2017 penggunaan jenis ekstrak yang berbeda dapat menghasilkan hasil yang berbeda juga(12,13).

\section{Uji Organoleptik}

Sebelum dilakukan uji stabilitas sediaan gel face scrub ekstrak Cucumis sativus., L dan ampas kelapa memiliki bentuk gel, warna bening butir putih, dan aroma yang tidak berbau. Berdasarkan hasil pengamatan uji organoleptik sediaan dapat dilihat tidak ada perubahan bentuk, warna, dan bau dari hari ke hari selama 3 bulan. Dapat disimpulkan bahwa uji organoleptik sediaan gel face scrub ekstrak Cucumis sativus.,L dan ampas kelapa stabil pada suhu ruang $\left(20-25^{\circ} \mathrm{C}\right)$ ), dibawah sinar matahari, dan pada suhu $40^{\circ} \mathrm{C}$.

\section{Uji pH}

dilihat dari grafik nilai $\mathrm{pH}$ yang disimpan pada suhu ruang $\left(20-25^{\circ} \mathrm{C}\right)$ ), di bawah sinar matahari, dan pada suhu $40^{\circ} \mathrm{C}$ mengalami penurunan dan kenaikan nilai $\mathrm{pH}$. Perubahan nilai $\mathrm{pH}$ disebabkan karena waktu penyimpanan yang terlalu lama sehingga sediaan kurang stabil. Selain itu, perubahan nilai $\mathrm{pH}$ terjadi karena faktor lain seperti suhu, lingkungan, dan kombinasi eksipien dalam sediaan sehingga mengalami oksidasi. Ekstrak buah mentimun yang diperoleh dari PT. Phytocemindo Reksa memiliki nilai pH 4,69 maka semakin tinggi konsentarsi ekstrak buah Cucumis sativus., L nilai pH sediaan akan semakin meningkat. Terdapat perbedaan nilai $\mathrm{pH}$ dari setiap formula gel disebabkan karena basis karbopol dengan konsentrasi 0,5\% - 1\% akan menghasilkan basis dengan $\mathrm{pH} 3$ yang kemudiaan jika ditambahkan dengan trietanolamin akan menghasilkan basis yang netral(14).

Hasil uji statistik menunjukkan bahwa nilai pH pada suhu ruang $\left(20-25^{\circ} \mathrm{C}\right) \mathrm{F} 1$, $\mathrm{F} 2$, dan F3 terdapat beberapa perbedaan yang signifikan dihari-hari tertentu dengan nilai $p$ value yang berbeda. Pada F1 terdapat perbedaan signifikan pada hari ke 1 menuju hari ke 7 dan hari ke 30 menuju hari 60 . Pada F2 terdapat perbedaan yang signifikan dari hari ke 7, 15, 30,60, dan 90 dan pada F3 hari ke 1 menuju hari ke 7 menuju hari ke 15 berbeda signifikan dengan nilai $<0,0001$. 
Pada penyimpanan dibawah sinar matahari terdapat perbedaan yang signifikan pada F1 dihari ke 1 menuju ke 7 dan pada F2 terdapat perbedaan signifikan pada hari ke 0 , ke 1 , ke 7 , dan ke 15 dengan $p$-value 0,0005 dan $<0,0001$. Perbedaan yang signifikan juga terjadi pada F3 dihari ke 1 dan 7, lalu hari ke 15 dan 30 dengan nilai p-value < 0,0001 dan 0,0031 .

Pada Penyimpanan Suhu $40^{\circ} \mathrm{C}$ terdapat perbedaan yang signifikan pada $\mathrm{F} 1$ di hari ke 1,15 , dan ke 30 dengan nilai $p$-value $0,0013,0,0494,<0,0001$.

\section{Uji Viskositas}

Viskositas sediaan gel face scrub ekstrak Cucumis sativus., L dan ampas kelapa pada suhu ruang $\left(20-25^{\circ} \mathrm{C}\right)$ ), di bawah sinar matahari, dan pada suhu $40^{\circ} \mathrm{C}$ mengalami peningkatan dan penurunan, namun hal ini tidak berpengaruh karena nilai yang tidak berbeda jauh dan menurut hasil statistik tidak terdapat perbedaan yang signifikan pada semua sediaan yang disimpan dalam berbagai suhu yang menandakan bahwa sediaan stabil. Nilai rata-rata viskositas pada semua suhu masih masuk kedalam range viskositas gel. Menurut SNI 16-4380- 1996 nilai viskositas sediaan gel pembersih kulit yaitu 3.000- 50.000 Centipois. Menurut Pertiwi et al., 2016, Viskositas carbopol akan mengalami penurunan jika berada dalam suasana asam, sehingga berdampak pada viskositas sediaan yang menurun, maka dari itu sediaan gel face scrub ekstrak Cucumis sativus.,L dan ampas kelapa tersebut memiliki nilai viskositas yang memenuhi syarat $^{(15)}$.

\section{Kesimpulan}

Dapat disimpulkan bahwa sediaan gel face scrub ekstrak cucumis sativus., L dan ampas kelapa stabil selama uji stabilitas dipercepat. Dari pengamatan uji organoleptik, uji pH , dan uji viskositas semua hasil masih sesuai dengan parameter masing-masing.

\section{Daftar Pustaka}

1. Tiwle, D. K. S. and R. Formulation and characterization of herbal face wash/scruber. European Journal of Pharmaceutical and Medical Research. 2016; 3(11), 274-278.

2. Aglawe, S. B., Gayke, A. U., Khurde, A., Mehta, D., Mohare, T., Pangavane, A., \& Kandalkar, S. Preparation and evaluation of polyherbal facial scrub. Journal of Drug Delivery and Therapeutics. 2019; 9(2), 61-63. https://doi.org/10.22270/jddt.v9i2.2380

3. Debbarma, D., Dona, D., Pk, M., Baidyanath, M., Vivekananda, R., \& Dimple, W. Clinical Review of Deep Cleansing Apricot Scrub: an Herbal Formulation. International Jornal of Bioassays. 2015; 4251-4253.

4. Ghode, D. S. P., Chatur, V. M., Ghode, D. P. D., Shaha, N., Prajapati, S., \& Thorave, A. Formulation And Evaluation Of Facial Scrub Containing Sunflower Seeds And Other Natural Ingredients. World Journal of Pharmaceutical Research. 2019; 8(9), 1772-1781. https://doi.org/10.20959/wjpr20199-15614 
5. Prathyusha, J., Yamani, N. S., Santhosh, G., Aravind, A., \& Naresh, B. Formulation and Evaluation of Polyherbal Face Scrubber for Oily Skin in Gel Form. International Journal of Pharmaceutical Sciences and Drug Research, 11(04), 126-128. https://doi.org/10.25004/ijpsdr.2019.110404

6. Emerald, M., Emerald, A., Emerald, L., \& Kumar, V. 2016. Perspective of Natural Products in Skincare. Pharmacy \& Pharmacology International Journal, 4(3). https://doi.org/10.15406/ppij.2016.04.00072

7. Lima, E. B. C., Sousa, C. N. S., Meneses, L. N., Ximenes, N. C., Júnior, M. A. S., Vasconcelos, G. S., Lima, N. B. C., Patrocínio, M. C. A., Macedo, D., \& Vasconcelos, S. M. M. Cocos nucifera.,L ( Arecaceae ): A phytochemical and pharmacological review. Brazilian Journal of Medical and Biological Research. 2015; 48(11), 953-964. https://doi.org/org/10.1590/1414-431X20154773

8. Putri, M. F. Kandungan Gizi Dan Sifat Fisik Tepung Ampas Kelapa Sebagai Bahan Pangan Sumber Serat. Teknobuga. 2014; 1(1), 32-43.

9. Pramuditha, N. Uji Stabilitas Fisik Lulur Krim Dari Ampas Kelapa (Cocos nucifera L.) Dengan Menggunakan Emulgator Anionik Dan Nonionik. 2016: Skripsi.

10. Agustin, V., \& Gunawan, S. Uji fitokimia dan aktivitas antioksidan ekstrak mentimun ( Cucumis sativus.,L ). Tarumanagara Medical Journal. 2019; 1(2), 195200

11. Andayani, R., Maimunah, dan Lisawati, Y. Penentuan Aktivitas Antioksidan, Kadar Fenolat Total dan Likopen pada Buah Tomat (Solanum lycopersicyum., L). Jurnal Sains dan Teknologi Farmasi. 2008 ;13(1) 31-37

12. Cruz, R.Y.D., Ang, A.M.G., Doblas, G.Z., Librando,I.L., Porquis, H.C., Batoctoy, B.C.L.S., Cabresos, C.C., Jacalan, D.R.Y., \& Amoroso, V.B. Phytochemical Screening, Antioxidant and Anti-inflammatiry Activities of the Three Fern (Polypodiaceae) Species in Bukidnon, Philippines. Bulletin of Environment, Pharmacology and Life Sciences. 2017;6(3) : 28-33

13. Raman, V., Rana, A. \& Sarma, A. Phytochemical Analysis \& Anthelmintic Activity Of Leaves Of Leucaena Leucocephala. World Journal of Pharmaceutical Research.2018;7:822-833.10.20959/wjpr201811-12411.

14. Rahmawati, D. A., \& Setiawan, I. The Formulation and Physical Stability Test of Gel Fruit Strawberry Extract (Fragaria $x$ ananassa Duch.). Journal of Nutraceuticals and Herbal Medicine. 2019; 2(1), 38-46

15. Mutmainah, Kusmita, L., \& Puspitaningrum, I. Pengaruh Perbedaan Konsentrasi Ekstrak Etanol Kulit Buah Manggis ( Garcinia mangostana L .) Terhadap Karakteristik Fisik Sediaan Gel. 2008, 98-104. 